\title{
Growth Failure and Decreased Bone Mineral of Newborn Rats with Chronic Furosemide Therapy
}

\author{
WINSTON W. K. KOO, ZHI-PING GUAN, REGINALD C. TSANG, PETER LASKARZEWSKI, AND \\ VICKI NEUMANN
}

\begin{abstract}
Division of Neonatalogy [W.W.K.K., Z-P.G., R.C.T., V.N.], Department of Pediatrics and Department of Biostatistics and Epidemology, [P.L.], University of Cincinnati College of Medicine and Cincinnati Children's Hospital Research Foundation, Cincinnati, Ohio 45267 and Department of Pediatrics [Z-P.G.], Guang Zhou Medical School, Guang Zhou, Peoples Republic of China
\end{abstract}

\begin{abstract}
To test the hypothesis that chronic furosemide treatment in otherwise healthy newborn animals may lead to lowered bone mineral [calcium (Ca) and magnesium $(\mathrm{Mg})$ ] content, healthy littermates within each litter of Sprague-Dawley rat pups were randomly assigned to three groups: control, low dose furosemide $(5 \mathrm{mg} / \mathrm{kg} / \mathrm{day})$, and high dose furosemide $(15 \mathrm{mg} / \mathrm{kg} / \mathrm{day})$. The pups were treated between days 4 and 28 postnatally. The wet and dry weights of kidneys and tibiae significantly correlated with body weights at sacrifice. Furosemide-treated pups demonstrated a dose-dependent growth delay, decreased total bone (tibiae) $\mathrm{Ca}$ and $\mathrm{Mg}$, increased urine $\mathrm{Ca}$ and $\mathrm{Mg}$ concentration, and a significant inverse correlation between bone $\mathrm{Ca}$ and urine $\mathrm{Ca}$ concentration. There was no significant difference among the groups when bone $\mathrm{Ca}$ and $\mathrm{Mg}$ were normalized to per gram of bone dry weight. There were no significant differences among the groups with respect to bone phosphorus or urinary phosphorus concentration; kidney and serum $\mathrm{Ca}$ and $\mathrm{Mg}$; or serum sodium, potassium, alkaline phosphatase and immunoreactive parathyroid hormone concentration. We conclude that chronic furosemide therapy leads to growth failure and to increased urinary losses of $\mathrm{Ca}$ and $\mathrm{Mg}$. Total bone $\mathrm{Ca}$ and $\mathrm{Mg}$ in the furosemide-treated pups were diminished in proportion to growth retardation but the bone mineral content per unit of dry weight remained similar to control pups. (Pediatr Res 20: 74-78, 1986)
\end{abstract}

Abbreviations

Ca, calcium

Mg, magnesium

$P$, phosphorus

$\mathrm{Na}$, sodium

$\mathrm{K}$, potassium

PTH, parathyroid hormone

Potent "loop" diuretics such as furosemide are frequently used in sick newborn infants. Their role in congestive cardiac failure and acute fluid overload is well established (1-3). These diuretics

Received May 6, 1985; accepted August 23, 1985.

Reprint requests Dr. Winston Koo, M.B.B.S., F.R.A.C.P., University of Cincinnati Medical Center, Department of Pediatrics, 231 Bethesda Avenue, Cincinnati, $\mathrm{OH}$ 45267-0541.

Supported in part by NIH RR 00123 and NIH RR 00068 (CLINFO). WK is a recipient of NIH Clinical Associate Physician Award 3M01RR 00123-22S1. ZPG was a recipient of a visiting scientist fellowship from the People's Republic of China. have been proposed to be beneficial for infants with acute (4-6) and chronic respiratory disorders (7). However, not all investigators support these uses (8-10) and there are increasing reports of complications associated with furosemide use in infants (1115). Anecdotal reports have associated chronic furosemide therapy in human newborns with renal calcification (13) and bone demineralization with secondary hyperparathyroidism (14). These complications are usually described in infants with complicated clinical courses. In these situations, there are usually multiple confounding variables including, e.g. variable nutritional intake (or lack of it) that might influence mineral metabolism in the sick infant. The aim of this study is to test the hypothesis that chronic furosemide administration alone can reduce bone mineral content in the healthy newborn rat.

\section{MATERIALS AND METHODS}

Healthy newborn littermates of Sprague-Dawley rats were randomly assigned (within each litter by drawing assignments from sealed envelopes) to a control group or to one of two furosemide-treated groups. If the litter size was large, it was culled to a maximum of nine pups to minimize the possibility of reduced or unequal nutritional intake for the pups. A total of nine litters were used.

Various concentrations of furosemide (Lasix, Hoechst-Roussel Ltd., N. Somerville, NJ) were prepared by dilution with preservative free sterile water so that the daily volume of injection remained between 0.1 and $0.4 \mathrm{ml}$ for each pup. The diluted furosemide solutions were kept in a syringe sealed from light at $4^{\circ} \mathrm{C}$ and fresh solutions were prepared every $48 \mathrm{~h}$. The furosemide treatment included a high dose $(15 \mathrm{mg} / \mathrm{kg} / \mathrm{day})$ and a low dose $(5 \mathrm{mg} / \mathrm{kg} /$ day) group. The quantity of furosemide was administered subcutaneously in equally divided doses twice daily from the 4th day until 28 days after birth. The dosage and volume of injection were adjusted twice weekly according to the weight of the pups to the nearest $5 \mathrm{~g}$. The pups were weighed with the same electronic scale (Fisher model 200, Ainsworth Div., Denver, CO) to the nearest $0.1 \mathrm{~g}$. The pups in the control group were given two subcutaneous injections of sterile water of equal volume to the treatment groups. The pups were allowed to nurse ad libitum throughout the study.

A spot urine collection was attempted using electrolyte free capillary tubes (Fisher Scientific Co., Cincinnati, $\mathrm{OH}$ ) applied to the external genitalia of the pups during the morning injection on day 28 . Thus the urine was collected $12 \mathrm{~h}$ after the previous injection. Six litters were sacrificed on day 28 and three litters were sacrificed on day 31 . The pups were sacrificed by exsanguination under ether anesthesia. Serum and urine samples were stored at $-20^{\circ} \mathrm{C}$ until assay.

A standardized radiograph of the whole body was taken of all 
the pups and analyzed for evidence of osteopenia and rickets and for evidence of renal calcification by one radiologist. Right tibia length of each pup was determined from the same radiograph with the same ruler to the nearest $\mathrm{mm}$ by one investigator (W.W.K.K.)

The kidneys were then removed and dissected clean of perinephric fat, and as much as possible of the renal pelvis and renal capsule were removed. Shafts of tibiae were dissected free of all soft tissue. Both kidneys were weighed together to the nearest $0.1 \mathrm{mg}$ (Mettler H51AR scale, Mettler Corp., Cleveland, $\mathrm{OH}$ ) as were both tibiae. Each organ was individually wrapped in parafilm and frozen at $-20^{\circ} \mathrm{C}$ until assay.

Prior to the ashing process, the kidneys and tibiae were placed in a drying oven at $100^{\circ} \mathrm{C}$ for 10 to $12 \mathrm{~h}$ and reweighed at 2- to 3-h intervals thereafter until irreducible dry weight was obtained. The kidneys and bones from each pup were then wet ashed separately in $70 \%$ nitric acid at $140^{\circ} \mathrm{C}$. The final ash solution was made up to $10 \mathrm{ml}$ with triple deionized water.

The serum, urine, and ashed samples of kidney (both kidneys) and bone (tibiae) were measured for $\mathrm{Ca}, \mathrm{Mg}$, and $\mathrm{P}$. In addition, serum concentrations of $\mathrm{Na}, \mathrm{K}$, alkaline phosphatase, and immunoreactive PTH were measured.

$\mathrm{Ca}$ and $\mathrm{Mg}$ concentrations of the serum and the ash sample were measured by atomic absorption spectrophotometry (16). P concentrations were measured by the method of Fiske and Subbarrow (17). Serum concentrations of $\mathrm{Na}$ and $\mathrm{K}$ were measured by ion selective electrode (IL 508, Lexington, MA); alkaline phosphatase was measured by the method of Wilkinson et al using a centrifugal analyzer (18). iPTH was measured by PTHmidmolecule radioimmunoassay (Immuno Nuclear Corp., Stillwater, $\mathrm{MN}$ ) with the addition of a rat standard (1000 pmol/liter). Units are expressed as picomoles human PTH equivalent (hPTHeq)/liter. The antiserum measures the midmolecule (44-68) amino acid sequence of the PTH molecule (19). In our laboratory, the interassay coefficient of variation for this assay is $9.6 \%$.

Analysis of covariance (20) was used to assess the effects of furosemide treatment and postnatal age on body weight for each group. One-way analysis of variance and Student Newman Keuls multiple range test were used to determine the differences among the three groups. Standard linear regression analysis were performed as indicated. Statistical calculations employed the CLINFO system software and were supplemented by the SAS program (21) of the NIH General Clinical Research Center, University of Cincinnati.
RESULTS

Twenty-five pups were randomly assigned to the control group, 25 to the low dose furosemide $(5 \mathrm{mg} / \mathrm{kg} /$ day) group and 27 pups to the high dose $(15 \mathrm{mg} / \mathrm{kg} /$ day $)$ furosemide group. On day 4 after birth, at the beginning of the study, there were no differences in the body weight of the pups among groups. There was a dose

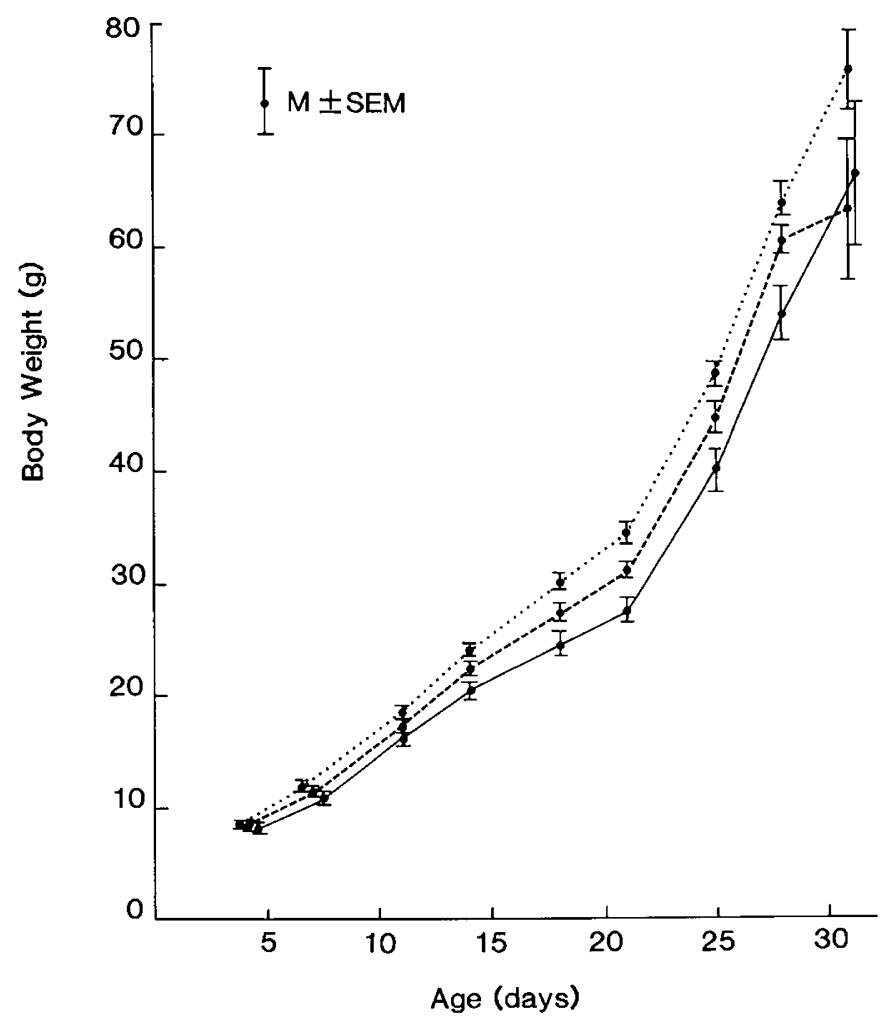

Fig. 1. Body weight (mean \pm SEM) of rat pups in the control ana furosemide treated groups. 10 , control group $(n=25) ;-\cdots$, low dose furosemide $5 \mathrm{mg} / \mathrm{kg} /$ day group $(n=25)$; ----, high dose furosemide 15 $\mathrm{mg} / \mathrm{kg} /$ day group $(n=27)$. Analysis of covariance for postnatal age and body weight. $p<0.004$ low dose furosemide group compared to control group; $p<0.001$ high dose furosemide group compared to control group; $p<0.03$ high dose furosemide group compared to low dose furosemide group.

Table 1. Changes in body wt, bone* and kidney* wt with various treatment regimens (mean \pm sem)

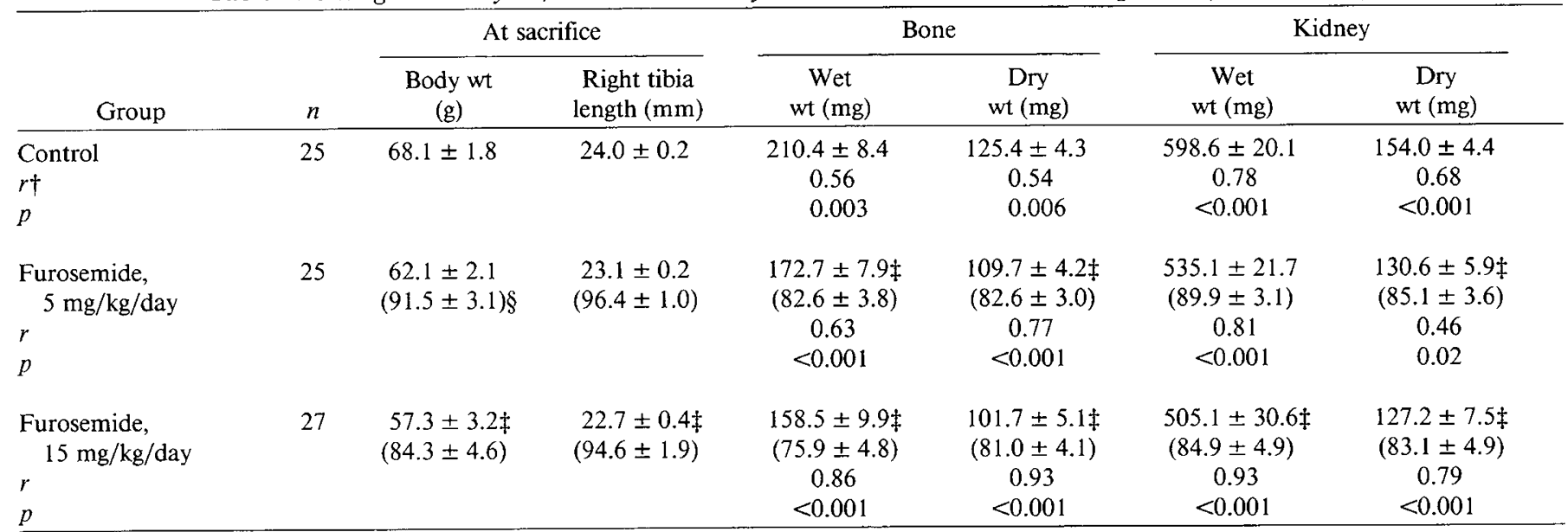

* Bone wt includes both tibae; kidney wt includes both kidneys from same pup.

$\dagger$ Correlation with body wt at sacrifice, linear regression analysis.

$\ddagger p<0.05$, compared to control group; one-way analysis of variance and Newman Keuls multiple range test.

$\S$ Numbers in parentheses are percentage of mean wt of littermate controls. 
dependent growth delay in the furosemide treated groups. The effect of age on weight was significantly different in each group, i.e. the shape of the growth curve for each group (best approximated by including a quadratic term for age) was significantly different from the other groups (Fig. 1).

There was significant lowering of body weight (Fig 1), of right tibia length, and of wet and dry weight of bone and kidney (Table 1) in the furosemide treated groups compared with the control group. There were no significance differences in the percent decrease in body weight and right tibia length at sacrifice for each of the treated groups.

Both the wet weight and dry weight of bone and kidney were correlated with body weight at sacrifice (Table 1). There were significant decreases in total bone (tibial) $\mathrm{Ca}$ and $\mathrm{Mg}$ in the furosemide treated groups compared with the control group. There were no differences among the groups with respect to total bone $\mathrm{P}$ and kidney $\mathrm{Ca}, \mathrm{Mg}$, and $\mathrm{P}$ contents (Table 2). There were no differences among the groups if the bone and kidney $\mathrm{Ca}, \mathrm{Mg}$, and $\mathrm{P}$ were normalized to per gram dry weight of tissue (Table 2).

There were no differences among the groups for any of the serum variables measured (Table 3). Attempts at urine collection were made on days $13,14,27$, and 28 days, but these attempts were successful only on day 28 . Urinary $\mathrm{Ca}$ and $\mathrm{Mg}$ concentrations on day 28 were significantly increased in the high dose furosemide group while urinary $\mathrm{P}$ concentrations were variable and did not show any difference among the groups (Table 4). Bone (tibial) Ca concentration was inversely correlated with urine Ca concentration (Fig. 2).

Whole body radiographs of the pups did not demonstrate any discernible bone abnormalities or renal calcification.

\section{DISCUSSION}

In this study, chronic furosemide therapy is associated with significant growth retardation and reduced total bone (tibial) $\mathrm{Ca}$ and $\mathrm{Mg}$ in young rat pups. Although the total bone $\mathrm{P}$ was not significantly reduced, it was reduced proportional to the $\mathrm{Ca}$ as would be expected. However, bone $\mathrm{Ca}, \mathrm{Mg}$, and $\mathrm{P}$, when expressed per gram of bone dry weight, were not different between the control and treated pups. These findings would imply that furosemide treatment results in a growth-retarded pup with small but normally mineralized bone. Biochemical and hormonal homeostasis as indicated by normal serum concentrations of $\mathrm{Ca}$, $\mathrm{Mg}, \mathrm{P}$, and $\mathrm{Ca}$ regulating hormone would further support the likelihood of small but normal bones in furosemide-treated pups. Similarity in bone radiographs also may be due to similar bone $\mathrm{Ca}, \mathrm{Mg}$, and $\mathrm{P}$ concentrations among the groups. Decreased bone mineral in this study is probably related to at least two mechanisms-growth delay and increased urinary $\mathrm{Ca}$ and $\mathrm{Mg}$ loss.

The growth delaying effect of chronic furosemide treatment may vary with the age at which therapy was begun. Warshaw et al. (22) demonstrated that furosemide at a dose of up to $200 \mathrm{mg} /$ $\mathrm{kg} /$ day when administered to rats with food for 25 days resulted

Table 4. Urine biochemical measurements of rat pup urine on last day of furosemide treatment (day 28) (mean \pm sem)

\begin{tabular}{cccc}
\hline Group & $\begin{array}{c}\mathrm{Ca} \\
(\mathrm{mg} / \mathrm{dl})\end{array}$ & $\begin{array}{c}\mathrm{Mg} \\
(\mathrm{mg} / \mathrm{dl})\end{array}$ & $\begin{array}{c}\mathrm{P} \\
(\mathrm{mg} / \mathrm{dl})\end{array}$ \\
\hline Control & $8.4 \pm 0.9$ & $11.9 \pm 2.2$ & $82.5 \pm 26.6$
\end{tabular}

$(4)^{*} \quad(4)$

(4)

$\begin{array}{cccc}\text { Furosemide, } & 11.3 \pm 1.6 & 14.1 \pm 1.4 & 80.4 \pm 17.3 \\ 5 \mathrm{mg} / \mathrm{kg} / \mathrm{day} & (9) & (9) & (6)\end{array}$

$\begin{array}{lccc}\text { Furosemide, } & 20.3 \pm 3.5 \dagger & 19.3 \pm 1.4 \dagger & 79.0 \pm 9.4 \\ 15 \mathrm{mg} / \mathrm{kg} / \text { day } & (8) & (8) & (5)\end{array}$

$\dagger p<0.05$ when compared to the control group. One-way analysis of variance and Newman Keuls multiple range test.

Table 2. $\mathrm{Ca}, \mathrm{Mg}$, and $\mathrm{P}$ content of bone (both tibae) and both kidneys (mean \pm sem)

\begin{tabular}{|c|c|c|c|c|c|c|}
\hline \multirow[b]{2}{*}{ Group } & \multicolumn{3}{|c|}{ Bone } & \multicolumn{3}{|c|}{ Kidney } \\
\hline & $\mathrm{Ca}(\mathrm{mg})$ & $\mathrm{Mg}(\mathrm{mg})$ & $\mathrm{P}(\mathrm{mg})$ & $\mathrm{Ca}(\mathrm{mg})$ & $\mathrm{Mg}(\mathrm{mg})$ & $\mathrm{P}(\mathrm{mg})$ \\
\hline $\begin{array}{l}\text { Control } \\
\quad(n=25)\end{array}$ & $\begin{array}{c}19.77 \pm 0.70 \\
(157.7 \pm 1.91)^{*}\end{array}$ & $\begin{array}{c}0.49 \pm 0.02 \\
(3.87 \pm 0.07)\end{array}$ & $\begin{array}{c}9.43 \pm 0.47 \\
(74.9 \pm 2.41)\end{array}$ & $\begin{array}{c}0.76 \pm 0.07 \\
(4.96 \pm 0.37)\end{array}$ & $\begin{array}{c}0.14 \pm 0.01 \\
(0.93 \pm 0.03)\end{array}$ & $\begin{array}{c}1.43 \pm 0.06 \\
(9.32 \pm 0.35)\end{array}$ \\
\hline $\begin{array}{l}\text { Furosemide, } \\
5 \mathrm{mg} / \mathrm{kg} / \text { day } \\
(n=25)\end{array}$ & $\begin{array}{r}17.47 \pm 0.71 \dagger \\
(158.8 \pm 1.66)\end{array}$ & $\begin{array}{c}0.43 \pm 0.01 \dagger \\
(3.98 \pm 0.08)\end{array}$ & $\begin{array}{c}8.31 \pm 0.41 \\
(76.2 \pm 3.03)\end{array}$ & $\begin{array}{c}0.71 \pm 0.05 \\
(5.72 \pm 0.47)\end{array}$ & $\begin{array}{c}0.13 \pm 0.01 \\
(1.08 \pm 0.10)\end{array}$ & $\begin{array}{c}1.32 \pm 0.06 \\
(10.59 \pm 0.68)\end{array}$ \\
\hline
\end{tabular}

* Numbers in parentheses are $\mathrm{Ca}, \mathrm{Mg}$, and $\mathrm{P}$ content/g dry wt of bone and kidney, respectively.

$\dagger p<0.05$, compared to control group; one-way analysis of variance and Newman Keuls multiple range test.

Table 3. Serum biochemical and hormonal measurements in rat pups (mean \pm sem)

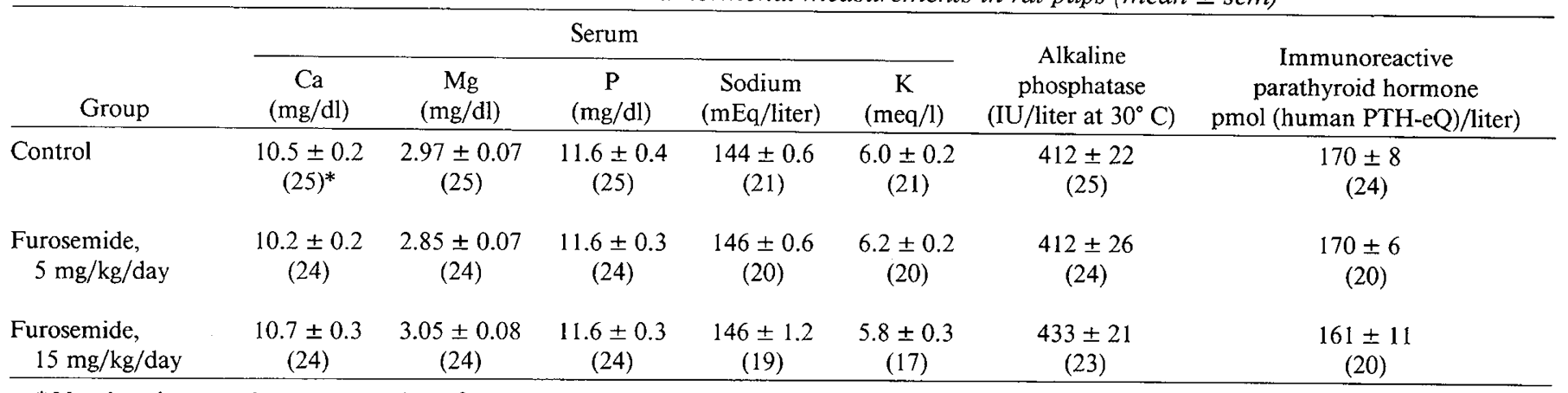

* Numbers in parentheses are number of rat pups measured. 


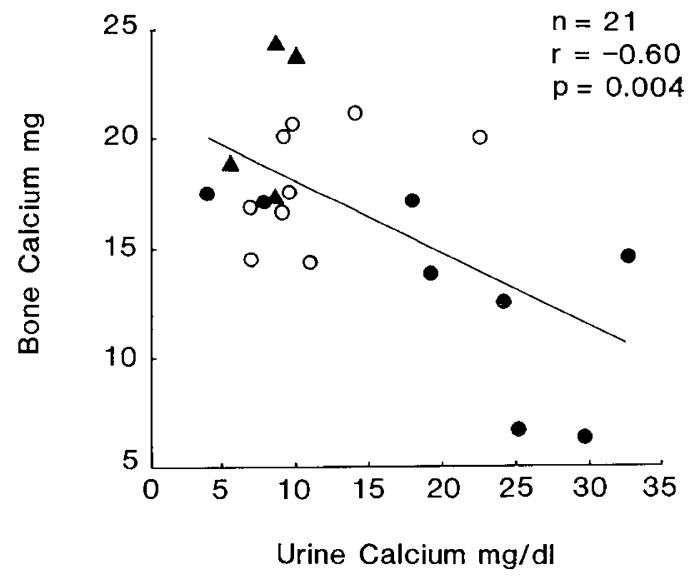

Fig. 2. Correlation between bone (tibial) calcium content and urine calcium concentration. Solid triangle, control group; open circle, low dose furosemide ( $5 \mathrm{mg} / \mathrm{kg} /$ day) group; closed circle, high dose furosemide $(15 \mathrm{mg} / \mathrm{kg} /$ day) group.

in an approximately $4.6 \%$ lower body weight compared to controls. In contrast, in this study of newborn rats, we demonstrated that the onset of growth delay in the furosemide-treated pups was early and marked. The extent of growth delay was proportional to the dose of furosemide given to the pups. During the study period, the increase in the mean body weight of control pups was approximately 9 -fold compared to an approximately 7 -fold increase in the mean body weight in the furosemidetreated groups. At the time of sacrifice, the difference in mean body weight between furosemide-treated and control pups was up to $16.5 \%$. It might be that younger animals in the present study, compared with 6-wk-old animals in the earlier study (22), are more sensitive to the growth delaying effect of furosemide treatment.

The mechanism of growth delay in chronic furosemide treatment is not known. In the rat, there is no agreement on whether growth delay is secondary to the effect of furosemide on $\mathrm{Na}$ depletion $(22,23)$. In humans, a renal compensatory effect of reduced $\mathrm{Na}$ excretion with chronic furosemide treatment has been reported (24). In the present study, the lowered body weight of the furosemide-treated pups probably was not due to extracellular or total body fluid changes, since there were no differences in serum concentrations of $\mathrm{Na}, \mathrm{K}, \mathrm{Ca}, \mathrm{Mg}$, and $\mathrm{P}$ among the groups, and organ (bone and kidney) wet and dry weights were highly correlated with body weight on sacrifice.

Diminished weight gain associated with metabolic alkalosis secondary to chloride deficiency has been reported in infants $(25)$ and in growing rats $(26,27)$. This may be related to the loss of appetite described in infants (25), but the effect on food consumption in growing rats may be variable $(22,26,27)$. Chronic furosemide administration also can induce a state of hypochloremic metabolic alkalosis (28). However, the normal serum $\mathrm{K}$ concentration of the pups in this study would offer indirect evidence against the presence of metabolic alkalosis. The use of littermates as control and treated groups, and, by design, limitations of litter size, should have minimized differences in nutrient intake for the pups.

Theoretically, chronic furosemide treatment may lead to growth delay by a number of other effects, e.g. altered body mineral (K, chloride) and trace element (zinc) status $(28,29-$ 32). Regardless of the mechanism(s) involved in growth delay, the slowing in the rate of weight gain became less pronounced with age, indicating possibly the ability of rat pups to at least partially compensate for the growth delaying effect of furosemide treatment.

It is well known that furosemide can increase urinary $\mathrm{Ca}$ excretion in human adults $(33,34)$, infants (13), and animals (22); the urinary excretion of $\mathrm{Mg}$ also is increased after furosemide administration $(22,28)$. From our data, it would seem that the urinary losses of $\mathrm{Ca}$ and $\mathrm{Mg}$ did not result in lowered serum concentrations of $\mathrm{Ca}$ and $\mathrm{Mg}$ and thus did not stimulate PTH release. In this study furosemide treatment was not associated with elevation in serum PTH concentrations. Since serum alkaline phosphatase concentrations were similar in all groups, increased bone turnover secondary to PTH excess also would be unlikely. Variable urinary $\mathrm{P}$ excretion has been reported in other studies of furosemide administration $(13,28)$. In this study, the effect of furosemide treatment on urinary $P$ loss was variable and not increased. The lack of increased urinary $P$ also would support the absence of secondary hyperparathyroidism in chronic furosemide treatment.

In hypercalciuric states $(35,36)$, it is conceivable that an increased gastrointestinal absorption of $\mathrm{Ca}$ may compensate for the urinary losses. However, this compensatory response is only partially effective; chronic furosemide therapy in 6-wk-old Sprague-Dawley rats has been associated with less positive $\mathrm{Ca}$ balance when compared to controls (22). From our data, it appears that intestinal $\mathrm{Ca}$ absorption was appropriate to meet the lowered demands of the slower growth rate of the furosemide-treated pups. Similar mechanisms might be operative for $\mathrm{Mg}$ metabolism, although there is no information in that regard. Nevertheless, it is conceivable that bone mineralization may be adversely affected to a greater extent if the balance among mineral needs for growth (which in this instance is reduced), mineral supply (mineral nutrient content and intestinal absorption), and mineral loss (from the prolonged use of potent diuretic) is disturbed. Thus, in theory, chronic furosemide therapy may be more likely to result in decreased bone mineralization in preterm infants who are fed human milk with mineral content that is low in relation to theoretic high mineral needs (37), when compared to rat pups which were fed rat milk with high mineral content appropriate for mineral needs (38). The inverse correlation between the urine $\mathrm{Ca}$ concentration and total tibial $\mathrm{Ca}$ content may be an additional factor associated with lowered bone $\mathrm{Ca}$.

In the present study there was no accumulation of $\mathrm{Ca}$ and $\mathrm{Mg}$ in the kidney tissue of furosemide-treated pups. Although the mean urinary $\mathrm{Ca}$ and $\mathrm{Mg}$ concentrations of the treated pups were approximately doubled compared to control pups, it is possible that the extent of urinary loss of $\mathrm{Ca}$ and $\mathrm{Mg}$ may be greater than that indicated from our results, since, because of technical reasons, urine samples were obtained only $12 \mathrm{~h}$ after the previous injection of furosemide. In infants, the peak urine $\mathrm{Ca}$ and $\mathrm{Mg}$ concentration from furosemide therapy is likely to be much greater than that measured in this study; urine excretion of $\mathrm{Ca}$ in infants who received furosemide therapy has been reported to be 10-fold higher than that of controls (13). Thus even in the absence of other factors such as acid base disturbances associated with chronic lung disease which may precipitate or aggravate any tendency to renal calcium precipitation, the prolonged use of potent diuretic theoretically can still predispose the infant to renal calculi and nephrocalcinosis (13).

In the present study, we demonstrated that in the young rat model, prolonged use of the potent diuretic furosemide has a growth inhibitory effect. Although the decreased total bone mineral is proportional to the growth delay, i.e. the bone mineral concentration remained normal, it is conceivable that in situations where a diminished supply or absorption of minerals occurs, such as frequently occurs in sick human preterm infants, there may be greater disturbances to bone mineralization as a result of chronic diuretic therapy.

Acknowledgments. The authors thank Mr. W. Brazerol and the staff of Department of Laboratory Animal Medicine for laboratory assistance, Dr. A. Oestreich for review of the X-rays, and Ms. A. Mattar for typing.

\section{REFERENCES}

1. Richardson $\mathrm{H} 1971$ Furosemide in heart failure of infancy. Arch Dis Child 46:520-524

2. Loggie JMH, Kleinman LI, VanMaanen EF 1975 Renal function and diuretic 
therapy in infants. Part III. J Pediatr 86:825-832

3. Lewy JE 1981 Diuretics in infancy. Contrib Nephrol 27:33-44

4. Moylan FMB, O'Connel KC, Todres ID, Shannon DC 1975 Edema of the pulmonary interstitium in infants and children. Pediatrics 55:783-787

5. Green TP, Thompson TR, Johnson DE, Lock JE 1983 Diuresis and pulmonary function in premature infants with respiratory distress syndrome. $J$ Pediatr 103:618-623

6. Najak ZD, Harris EM, Lazzara A Jr, Pruitt AW 1983 Pulmonary effects of furosemide in premature infants with lung disease. J Pediatr 102:758-763

7. Kao LC, Warburton D, Sargent CW, Platzker ACG, Keens TG 1983 Furosemide acutely decreases airways resistance in chronic bronchopulmonary dysplasia. J Pediatr 103:624-629

8. Savage MO, Wilkinson AR, Baum JD, Robertson NR 1975 Furosemide in respiratory distress syndrome. Arch Dis Child 50:709-713

9. Finberg L 1983 Furosemide-uses, abuses, and unsolved puzzles. Am J Dis Child 137:1145

10. Marks KH, Berman W Jr, Friedman Z, Whitman V, Lee C, Maisels MJ 1978 Furosemide in hyaline membrane disease. Pediatrics 62:785-788

11. Whitington BF, Black DD 1980 Cholelithiasis in premature infants treated with parenteral nutrition and furosemide. J Pediatr 97:647-649

12. Green TP, Thompson TR, Johnson D, Lock JE 1981 Furosemide use in premature infants and appearance of patent ductus arteriosus. Am J Dis Child 135:239-243

13. Hufnagle KG, Khan SN, Penn D, Cacciarelli A, Williams P 1982 Renal calcifications: a complication of long-term furosemide therapy in preterm infants. Pediatrics 70:360-363

14. Venkataraman PS, Han BK, Tsang RC, Daugherty CC 1983 Secondary hyperparathyroidism and bone disease in infants receiving long-term furosemide therapy. Am J Dis Child 137: 1157-1161

15. Cashore WJ, Oh W, Brodersen R 1983 Bilirubin-displacing effect of furosemide and sulfisoxazole. An in vitro and in vivo study in neonatal serum. Dev Pharmacol Ther 6:230-238

16. Sunderman FW Jr, Carroll JE 1965 Measurements of serum calcium and magnesium by atomic absorption spectrometry. Am J Clin Pathol 43:302310

17. Natelson S 1971 Techniques of Clinical Chemistry, 3rd ed. Charles C Thomas, Springfield, IL, pp 576-579

18. Wilkinson JH, Boutwell JH, Winsten S 1969 Evaluation of a new system for the kinetic measurement of serum alkaline phoshatase. Clin Chem 15:487495

19. 1982 Rat and mouse PTH by radioimmunossay. Immuno Nuclear Corp, Stillwater, MN

20. Searle SR 1971 Linear Models. John Wiley \& Sons, New York
21. 1982 SAS User's Guide: Statistics. SAS Institute Inc, Cary NC

22. Warsaw BL, Anand SK, Kerian A, Lieberman E 1980 The effect of chronic furosemide administration on urinary calcium excretion and calcium balance in growing rats. Pediatr Res 14:1118-1121

23. Fine BP, Ty A, Maher E, Bastidas A, Levine OR 1983 Diuretic induced growth failure in weanling rats. Pediatr Res 17 (suppl):188A

24. Wilcox CS, Mitch WE, Kelly RA, Skorecki K, Meyer TW, Friedman PA, Souney PF 1983 Response of the kidney to furosemide. 1. Effects of salt intake and renal compensation. J Lab Clin Med 102:450-458

25. Grossman H, Duggan E, McCamman S, Welchart E, Helchart E, Hellerstein S. The dietary chloride deficiency syndrome. Pediatrics 1980;66:366-374

26. Greenberg DM, Cutherbertston EM 1942 Dietary chloride deficiency and alkalosis in the rat. J Biol Chem 145:179-187

27. Voris L, Thacker EJ. The effects of the substitution of bicarbonate for chloride in the diet of rats on growth, energy and protein metabolism. J Nutr $1942 ; 23: 365-374$

28. Mudge GH. Diuretics and other agents employed in the mobilization of edema fluid. In: Goodman LS, Gilman AG, Gilman A (eds) 1980 The pharmacological basis of therapeutics. MacMillan Publ Co, New York, 6th ed, pp 892915

29. Sulyok E, Varga F, Nemeth M, Tenyi I, Csaba IF, Ertl T, Gyory E 1980 Furosemide-induced alterations in the electrolyte status, the function of renin-angiotensin-aldosterone system, and the urinary excretion of prostaglandins in newborn infants. Pediatr Res 14:765-768

30. Reynolds JEF, Prasad AB (eds) 1982 Martindale the Extra Pharmacopoeia, 28th ed. The Pharmacentical Press, London, pp 596-600

31. Wester PO 1980 Zinc balance before and during treatment with bendroflume thiazide. Acta Med Scand 208:265-267

32. Wester PO 1980 Tissue zinc at autopsy-relation to medication with diuretics. Acta Med Scand 208:269-271

33. Tambyah JA, Lim MKL 1969 Effect of furosemide on calcium excretion. $\mathrm{Br}$ Med J 1:751-752

34. Toft $\mathbf{H}$, Roin $\mathbf{J} 1971$ Effect of furosemide administration on calcium excretion. Br Med J 1:437-438

35. Lawoyin S, Sismilich S, Browne R, Pak CYC 1979 Bone mineral content in patients with calcium urolithiasis. Metabolism 28:1250-1254

36. Breslau NA, McGuire JL, Zerwekh JE, Pak CYC 1982 The role of dietary sodium on renal excretion and intestinal absorption of calcium and on vitamin D metabolism. J Clin Endocrinol Metab 55:369-373

37. Koo WWK, Tsang RC 1984 Bone mineralization in infants. Prog Food Nutr Sci 8:229-302

38. Luckey TD, Mende TJ, Pleasants J 1955 The Physical and chemical characterization of rats milk. J Nutr 54:345-359 